\title{
Comparative assessment of apple fruit storability during storage in different modes of the cooled medium
}

\author{
Yu.V. Plugatar, A.I. Sotnik, O.A. Denisova*, R.D. Babina, and N.N. Gorb
}

Federal State Budgetary Institution of Science Nikitsky Botanical Garden - National Scientific Center of the RAS, 52 Nikitskiy Spusk str., Nikita Settlement, 298648, Yalta, Republic of Crimea, Russian Federation

\begin{abstract}
The article presents the research results of the effect of postharvest treatment with Phytomag preparation of fruits of 21 apple tree varieties of domestic and foreign breeding on their storability and quality. The purpose of the research is to determine the effectiveness of the combined effect of such technological techniques as post-harvest fruit treatment with Phytomag preparation and their storage in conventional (CGD) and regulated (RGD) gas dynamics on the formation of quality and storability of apples grown in the Crimea. The data obtained showed that the treatment of fruits with an ethylene inhibitor Phytomag during storage in conventional and regulated gas dynamics reduces losses, depending on the variety, by $1.5-1.8$ times. It is established that the processed fruits retain their original marketable appearance, have high quality components during the entire storage period and after opening the refrigerating chambers, selling the fruits and bringing them to the consumer. It is proved that in the conditions of the Crimea such varieties as Tavria, Krymskoye Zimnee, Krymskoye, Orion, Kimmeria, Brebern, Fuji, Idared, Pink Lady can be successfully stored in a conventional gas dynamic with post-harvest treatment with preparation inhibiting ethylene synthesis. The advantage of storage in regulated gas dynamic was shown by the varieties Aromat Kryma, Predgornoye, Golden Delicious, Crispin, Granny Smith, Glouster, Gala, Jonagold.
\end{abstract}

\section{Introduction}

The strategic goal of any state is to ensure food security. Fruits and berries, as well as products of their processing, belong to the group of functional and preventive products, the use of which contributes to improving human immunity, prevention of cardiovascular diseases, removal of radionuclides, heavy metals and other toxic elements from the body, which is especially important due to the deterioration of the environmental and epidemiological situation [1].

\footnotetext{
* Corresponding author: sadovodstvokrim@mail.ru
} 
The apple tree is the leading one in the structure of fruit plantations in the Crimea. In the future, its share will be $60-65 \%$ of the area. According to the Ministry of Health of the Russian Federation, the physiological norm of apple consumption per year should be $50 \mathrm{~kg}$, per day $-137 \mathrm{~g} /$ person $[2,3]$. Apples are in great demand due to their taste qualities. They are classified as valuable food products having not only nutritious, but also medicinal properties [4,5]. With the selection of apple tree varieties and the proper organization of storage, it is possible to provide the population and vacationers of the peninsula with fresh fruits throughout the year. The breeders of the Crimean Experimental Horticulture Station have created apple tree varieties that have significant adaptive potential to the rather difficult soil and climatic conditions of the Crimean Peninsula. They are distinguished by high fruit productivity and marketability. Most of the varieties belong to the winter group and are suitable for long-term storage.

New technologies combining fruit storage with post-harvest fruit treatment with an ethylene biosynthesis inhibitor 1- methylcyclopropene (Phytomag, Smartfresh, etc.) can significantly reduce losses from diseases and preserve the quality of fruits [6,7]. Existing storage technologies in a conventional cooled gas dynamic (CGD), regulated gas dynamic (RGD) and modified (MGD) with different concentrations of oxygen and carbon dioxide have their advantages and disadvantages, differ in the costs of their implementation, but require optimization of technological storage parameters considering varietal characteristics of fruits $[8,9]$.

The purpose of the research is to determine the effect of post-harvest treatments of fruits of different apple varieties, when stored in conventional and regulated gas dynamics, on the formation of their quality and storability during the period of bringing products to the consumer.

\section{Materials and methods of research}

The object of research was the fruits of apple trees of the breeding of the "Crimean Experimental Horticulture Station" (now FSSI "NBS-NNC") - Predgornoye, Orion, Tavria, Aromat Kryma, Krymskoye Zimneye, Aurora Krymskaya, Krymskoye, Cimmeria as well as introduced Pink Lady, Fuji, Golden Delicious, Granny Smith, Idared, Glouster, Golden Rainders, Brebern, Crispin, Red Delicious, Jonagold, Gala, Renet Simirenko.

The research was carried out on the basis of experimental plantings and an experimental refrigerator of the FSSI "NBS-NNC" Crimean Experimental Gardening Station, as well as at the production and experimental bases of JSC Crimean Fruit Company of the Krasnogvardeisky and CJSC Yarosvit Agro of the Simferopol districts.

The fruits of the studied late-ripening varieties underwent post-harvest treatment with Phytomag preparation and were stored in a conventional gas dynamic and regulated one with a content of $1.5-1.8 \% \mathrm{O} 2$ and $2.0-2.5 \% \mathrm{CO} 2$. The control was fruits stored in the same dynamic without post-harvest treatment. The fruits were removed and stored in picking maturity and corresponded to the highest and first grades (GOST34314 - 2017).

The work was carried out according to the "Program and methodology of variety study of fruit, berry and nut crops" [19], "Methodology of field experience" [20].

The content of soluble solids was determined according to GOST ISO 2173-2013; sugars by the Bertrand method, ascorbic acid - by the accelerated method according to A.I. Ermakov [21]; titratable acids - GOST ISO 750 - 2013; starch - iodine starch sample; pulp density - penetrometer. The natural loss of fruit weight was determined by weighing fixed samples. The storage temperature of fruits is $0^{\circ}-+1^{\circ} \mathrm{C}$, air humidity is $85-90 \%$. 


\section{Results and discussion}

The results of the performed studies indicate that after storage of apples, both in the CGD and in the RGD, the experimental samples with Phytomag preparation treatment had higher pulp density indicators compared to the control ones (Table 1). Thus, when storing Golden Delicious apples treated with Phytomag, after 250 days of storage in the RGE, the pulp density index was 1.2 times higher than in the control.

Table 1. Indicators of the pulp density of apple fruits when stored in the RGD, depending on the variety and treatment with Phytomag preparation, harvest of 2017-2019.

\begin{tabular}{|c|c|c|c|c|}
\hline \multirow[t]{2}{*}{ Variety } & \multirow[t]{2}{*}{ Variant } & \multicolumn{3}{|c|}{ Pulp density, $\mathrm{kg} / \mathrm{cm}^{2}$} \\
\hline & & $\begin{array}{l}\text { laying for } \\
\text { storage }\end{array}$ & $\begin{array}{l}\text { after } 100 \text { days of } \\
\text { storage }\end{array}$ & $\begin{array}{c}\text { after } 250 \text { days } \\
\text { of storage }\end{array}$ \\
\hline \multirow[t]{2}{*}{ Krymskoye } & Control & \multirow[t]{2}{*}{9.0} & 7.2 & 6.8 \\
\hline & $\begin{array}{l}\text { Treatment with } \\
\text { Phytomag }\end{array}$ & & 8.4 & 8.0 \\
\hline \multirow{2}{*}{$\begin{array}{l}\text { Golden } \\
\text { Delicious }\end{array}$} & Control & \multirow[t]{2}{*}{8.6} & 6.8 & 6.4 \\
\hline & $\begin{array}{l}\text { Treatment with } \\
\text { Phytomag }\end{array}$ & & 7.9 & 7.5 \\
\hline \multirow[t]{2}{*}{ Fuji } & Control & \multirow[t]{2}{*}{8.2} & 6.0 & 5.6 \\
\hline & $\begin{array}{l}\text { Treatment with } \\
\text { Phytomag }\end{array}$ & & 7.5 & 6.4 \\
\hline
\end{tabular}

A similar dependence was noted for other varieties. Minimal changes are noted on the variants with the preparation treatment, which ensures long-term storage of fruit quality after removing them from the refrigerator.

The decrease in the marketability of fruits during storage in the CGD occurred due to subcutaneous spotting and fungal rot; in the RGD with treatment - only due to slight rotting of fruits after mechanical damage during removal and transportation.

The decrease in the natural weight loss of fruits treated with the preparation, in comparison with the control variants, was $1.41 \%$. The yield of standard fruits at the end of storage in RGE with preparation treatment was 98.7-99.9\%, in RGE without treatment 96.0-98.1. The indicators of taste qualities of most varieties are in the range of 4.6-5.0 points.

Thus, during our research, the positive effect of post-harvest treatment of apples with Phytomag preparation on their preservation has been proven. The treatment of apples with the preparation showed that the manifestation of functional diseases is inhibited for 1.2-2.0 months in such fruits, the amount of waste due to defect is only $0.2-0.5 \%$. The preparation provides protection of fruits from sunburn, wet burn, decay, browning and oily skin from aging, decomposition of tissues from mechanical damage, reduces losses from fungal rot and natural loss of apple mass when stored in CGD and RGD. It reliably preserves the hardness, juiciness, crispy consistency, marketable condition, taste of fruits during storage and delivery to the consumer when the cold chain breaks (commodity treatment, transportation, sale). The possibility of extending the period of fruit picking used for storage is achieved. The shelf life of apple fruits with low storability (fruits of summer and autumn varieties) is significantly extended. 
A comparative study of the indicators for assessing the storability of fruits was carried out in a conventional refrigerator with free access of air and in a regulated gas dynamic (Table 2).

Table 2. Comparative characteristics of apple fruit storage indicators in CGD and RGD (refrigerators KOSS and JSC "KFK"). Harvest 2016-2018

\begin{tabular}{|c|c|c|c|c|c|c|c|c|}
\hline \multirow[t]{2}{*}{ Variety } & \multicolumn{2}{|c|}{$\begin{array}{c}\text { Storage } \\
\text { duration, days }\end{array}$} & \multicolumn{2}{|c|}{$\begin{array}{l}\text { Yield of standard } \\
\text { fruits, } \%\end{array}$} & \multicolumn{2}{|c|}{$\begin{array}{l}\text { Natural loss of } \\
\text { mass, } \%\end{array}$} & \multicolumn{2}{|c|}{$\begin{array}{c}\text { Taste qualities, } \\
\text { score }\end{array}$} \\
\hline & CGE & RGE & CGE & RGE & $\begin{array}{c}\text { CG } \\
\mathrm{E}\end{array}$ & RGE & CGE & RGE \\
\hline \multicolumn{9}{|l|}{ Domestic } \\
\hline $\begin{array}{c}\text { Aurora } \\
\text { Krymskaya }\end{array}$ & 125 & 210 & 82.1 & 97.2 & 3.92 & 3.75 & 4.2 & 4.5 \\
\hline Cimmeria & 170 & 220 & 88.5 & 97.0 & 4.12 & 4.70 & 4.3 & 4.5 \\
\hline Krymskoye & 180 & 240 & 92.7 & 98.2 & 4.75 & 4.95 & 4.6 & 4.8 \\
\hline $\begin{array}{c}\text { Krymskoye } \\
\text { Zimneye }\end{array}$ & 200 & 270 & 94.5 & 98.5 & 4.52 & 4.79 & 4.6 & 4.9 \\
\hline Orion & 180 & 240 & 82.5 & 95.4 & 5.40 & 5.97 & 4.6 & 4.8 \\
\hline Predgornoye & 120 & 180 & 75.0 & 92.8 & 3.77 & 4.02 & 4.0 & 4.6 \\
\hline Tavria & 190 & 270 & 85.3 & 99.8 & 7.42 & 5.93 & 4.3 & 4.7 \\
\hline \multicolumn{9}{|l|}{ Foreign } \\
\hline Idared & 160 & 190 & 93.5 & 99.0 & 4.95 & 4.05 & 4.4 & 4.7 \\
\hline Brebern & 170 & 270 & 93.7 & 99.8 & 3.35 & 4.85 & 4.2 & 4.5 \\
\hline Gala & 125 & 200 & 68.5 & 96.7 & 8.85 & 5.17 & 5.0 & 5.0 \\
\hline Glouster & 125 & 210 & 78.0 & 95.3 & 6.32 & 5.11 & 3.8 & 4.2 \\
\hline $\begin{array}{l}\text { Golden } \\
\text { Delicious }\end{array}$ & 140 & 220 & 78.5 & 99.0 & 5.87 & 5.12 & 4.8 & 4.8 \\
\hline $\begin{array}{l}\text { Golden } \\
\text { Rainders }\end{array}$ & 170 & 270 & 82.7 & 99.5 & 6.95 & 5.83 & 4.2 & 4.7 \\
\hline Granny Smith & 95 & 190 & 70.3 & 96.4 & 5.17 & 4.35 & 3.8 & 4.2 \\
\hline Jonagold & 130 & 270 & 78.5 & 95.2 & 4.25 & 5.15 & 4.2 & 4.8 \\
\hline Crispin & 120 & 210 & 70.4 & 96.5 & 5.35 & 4.42 & 4.0 & 5.0 \\
\hline Pink Lady & 180 & 260 & 98.5 & 99.8 & 4.40 & 4.52 & 4.7 & 4.8 \\
\hline $\begin{array}{c}\text { Renet } \\
\text { Simirenko }\end{array}$ & 130 & 210 & 70.2 & 98.5 & 3.29 & 4.22 & 4.5 & 4.3 \\
\hline Fuji & 170 & 270 & 92.5 & 99.8 & 4.85 & 5.25 & 4.5 & 4.8 \\
\hline
\end{tabular}


It was found that in the OGS, the storability of apples of the Crimean Winter, Orion, Crimean, Cimmeria, Tavria, Idared, Brebern, Golden Rangers, Pink Lady, Fuji varieties was 170-200 days with the yield of standard fruits $82.5-98.5 \%$; the indicators of daily natural weight loss were in the range of $0.0340-0.0372 \%$. The indicators of Jonagold and Golden Delicious are slightly lower (130-140 days; 78.5\%). The decrease in marketability was mainly due to wilting. The minimum storage indicators in the CGD had varieties Crispin (a decrease in marketability to $70.4 \%$ due to subcutaneous spotting and bitter pit), Granny Smith (skin browning), Krymskoye Naryadnoye, Gala (wilting).

In a controlled gas dynamic, all the above varieties persisted longer - for 180-270 days, had a yield of standard fruits at the level of $92.8-99.8 \%$. The taste qualities of most varieties are in the range of 4.5-5.0 points, which is slightly higher in comparison with similar storage indicators in a conventional gas dynamic, with the exception of the fruits of Renet Simirenko. The fruits of this variety in the CGD were preserved for 130-150 days in different years, the standard yield was $70-80 \%$. In RGD, the shelf life and marketability are higher (210 days or more; $98.5 \%$ ), but the taste qualities are $0.2-0.3$ points lower compared to storage in a conventional gas dynamic. These data are consistent with the results obtained for the same variety during treatment with Phytomag and storage in the RGD. The decrease in taste and marketability occurred due to compaction and slight darkening of the pulp 3-5 days after the end of the shelf life.

Thus, in a controlled gas dynamic, compared with storage in a conventional air dynamic, the organoleptic properties and quality of fruits are better preserved, the green color remains longer, the hydrolytic processes of protopectin cleavage are slowed down (fruits remain solid longer). The use of RGD makes it possible to mitigate the aftereffect of the negative impact of adverse weather conditions and extend the storage period of apples. The RGD also compensates for the insufficiently effect of cold during long-term storage in the CGD.

At the same time, during our research, it was found that the quality of fruits of many winter apple varieties when stored in the CGD with apple treatment with an ethylene inhibitor Phytomag for 4-6 months is not lower than when stored in the RGD. Considering the fact that currently not all farms have refrigerators with RGD, or their volume is insignificant, we consider it possible and expedient to store such varieties as Aurora Krymskaya, Tavria, Krymskoye Zimneye, Orion, Cimmeria, Krymskoye, Brebern, Fuji, Idared, Pink Lady, in a conventional gas dynamic with treatment with Phytomag preparation or other analogues of the preparation 1-methylcyclopropene.

Such a variety as Golden Delicious has the advantage of storage in the controlled gas dynamic (the profit in the RGD is $1.5-2.0$ times higher compared to the CGD, high quality of fruits). The maximum effect was obtained when storing this variety in the RGD with Phytomag treatment and the sale of apples in May-June, since in the course of research it was proved that the effect of Phytomag treatment is not short-term, it persists during the entire storage time and after the opening of the refrigerating chambers, the sale of fruits, bringing them to the consumer. It is advisable to store in the CSG such varieties as Predgornoye, Aromat Kryma, Crispin, Granny Smith, Glouster, Gala, Jonagold. Regarding the latter variety, it should be noted that despite the low profit, the fruits in the RGD have high taste qualities and acquire a beautiful presentation. When stored in the CGD of such a variety as Gala, it was revealed that its fruits wilt greatly; in conditions of hot and very dry summer, they gain color poorly and, in the presence of even small precipitation, form cracks near the fruit stalk, transferring almost a large half of the crop to a non-standard. At the same time, they are preserved very well in the RGD for 180-200 days. The yield of standard fruits is $97 \%$, which is $28 \%$ higher compared to storage in the CGD; the profit, respectively, is 3.5 times higher. 
In recent years, to reduce functional diseases, a varietal step-by-step technology for storing apples has been recommended. The approbation of the developed varietal individual storage technology was carried out on the example of the Granny Smith variety on the basis of JSC "KFK". The elements of this technology are the following: targeted varietal agrotechnics (control over fertilization, irrigation, pruning of the garden, etc.), picking of the fruits in optimal technical maturity with pulp density of $9.5-10.5 \mathrm{~kg} / \mathrm{cm}^{2}$ and accumulation of dry soluble substances of at least $14 \%$, processing of products immediately after removal with ethylene inhibitors, storage for 30 days in the CGD at a temperature of $+2{ }^{\circ} \mathrm{C}$, gradual transition of the CGD to the RGD and super-RGD with oxygen concentration of $1.2 \%$, carbon dioxide $-2.0 \%$.

The research results showed that the fruits were stored until the end of June and for another month in the warehouse without signs of skin browning with good taste qualities (4.3-4.5 points), high yield of standard fruits and minimal amounts of non-standard products and waste (Fig. 1).

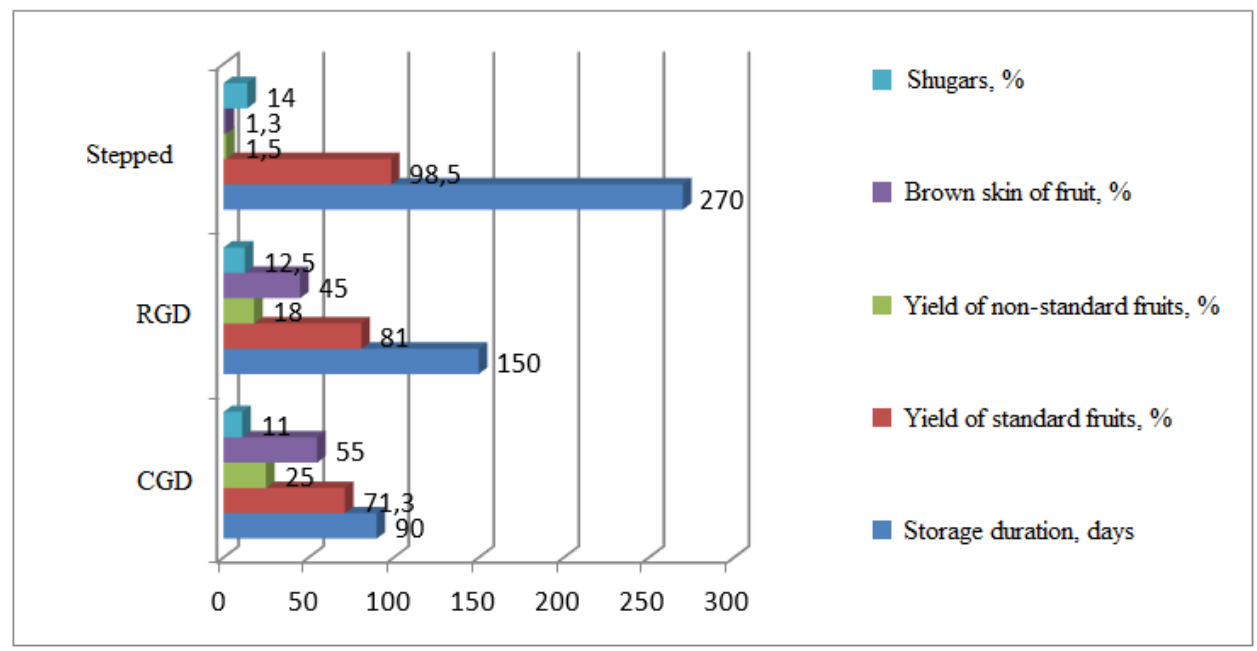

Fig. 1. Comparative assessment of the storability of Granny Smith fruits in different storage modes.

Based on the data obtained, a comparative assessment of the efficiency of fruit storage, considering varietal characteristics, was carried out in CGD, RGD, RGD with Phytomag treatment (Fig. 2).

Data analysis on the example of the Golden Delicious variety shows that, at the end of the shelf life, the selling price of fruits is $35-40 \%$ higher when sold after storage in the RGD and the maximum - after storage in the RGD with Phytomag treatment. Storage of fruits for 220-250 days in the RGD can significantly increase profitability and ensure a profit of 38.3-40.5 thousand rubles per 1 ton of fruits, which is almost 2.5 times more than the profit increase due to storage in the CGD. The maximum profit was obtained on the option with post-harvest treatment of apples with Phytomag and their further storage in the RGD. In general, the Krymskoye Zimneye, Orion, Tavria; Idared, Brebern, Golden Rainders, Pink Lady, Fuji showed high profit rates due to storage in the CGD and RGD; in the RGD - Predgornoye, Reinet Simirenko, Golden Delicious, Granny Smith, Crispin, Gala, Glouster, Jonagold. 


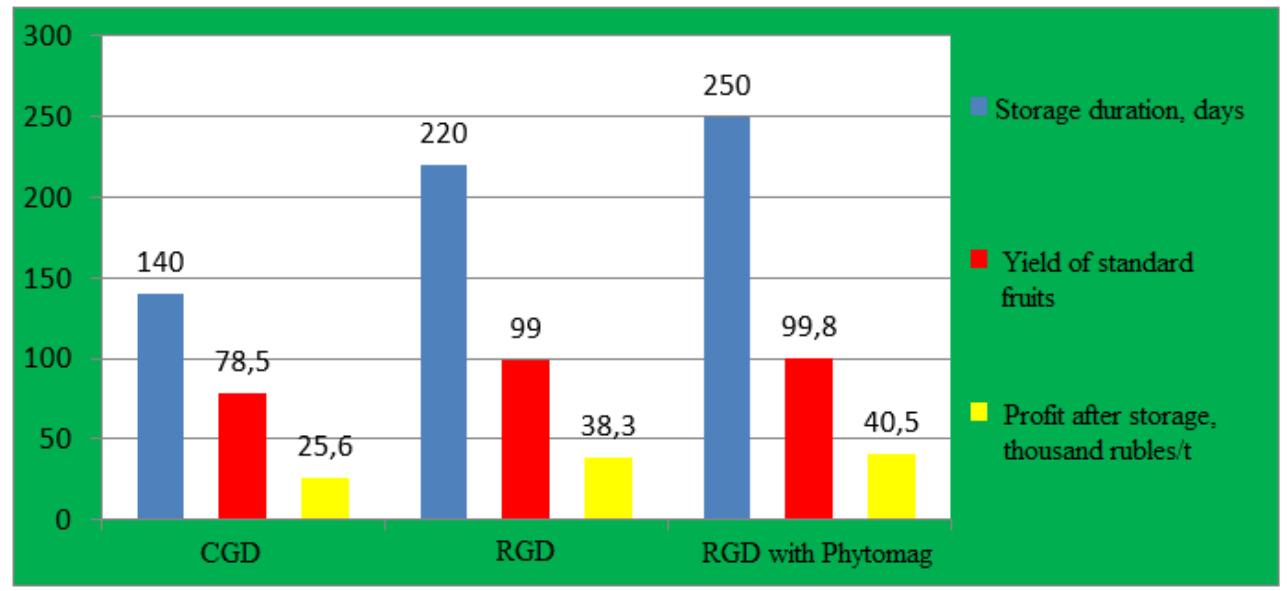

Fig. 2. Some indicators of storage of Golden Delicious apples in CGD, RGD and RGD with postharvest treatment with Phytomag.

\section{Conclusions}

The data obtained confirm the high efficiency of post-harvest treatment of the fruits of the studied apple tree varieties with an ethylene inhibitor Phytomag in combination with storage in conventional and regulated gas dynamics, providing a 1.5-1.8-fold reduction in losses.

In the process of work, it is proved that treatment effect is not short-term, it persists during the entire storage time and after opening the refrigerating chambers, selling the fruits and bringing them to the consumer. Processed fruits retain their original marketable condition, taste and quality indicators.

As a result of the comparative characteristics of the storage indicators of different apple varieties in the CGD and RGD, it was found that such varieties as Tavria, Zimneye Krymskoye, Krymskoye, Orion, Cimmeria, Brebern, Fuji, Idared, Pink Lady can be successfully stored in a conventional gas dynamic with post-harvest treatment with preparations that inhibit the ethylene synthesis.

The advantage of storage in the RGD was shown by the varieties Aromat Kryma, Predgornoye, Golden Delicious, Crispin, Granny Smith, Glouster, Gala, Jonagold.

The Krymskoye Zimneye, Orion, Tavria; Idared, Brebern, Golden Rainders, Pink Lady, Fuji showed the highest profit rates due to storage in the CGD and RGD; in the RGD Predgornoye, Reinet Simirenko, Golden Delicious, Granny Smith, Crispin, Gala, Glouster, Jonagold.

\section{Acknowledgements}

The work was conducted under public assignment № 0829-2019-0033; 0829-2019-0026

\section{Conflict of interest}

The author of the article confirms the absence of a conflict of interest, which must be reported. Not declared. 


\section{References}

1. Z. I. Arifova, E. F. Chelebiev, A. V. Smykov, E. S. Khalilov, M. K. Uskov, E3S Web Conf. (FARBA 2021), 254 (2021) https://doi.org/10.1051/e3sconf/202125 401015

2. Yu. V. Plugatar, A. I. Sotnik, R. D. Babina, Collected scientific works of the State. Nikit. Bot. Gard. (Yalta), 144(1), 227-235 (2017) (In Russ.)

3. Z. N. Khatko, E. N. Kolodina, New technologies 2(48), 118-137 (2019) (In Russ.)

4. N. N. Gorb, A. E. Untilova, Collection of works "Tavrichesky bulletin of agrarian science" 2, 49-55 (2013) (In Russ.)

5. E. R. Khubaeva, L. H. Tokhtieva, V. B. Tsuchkieva, Improving methods of storing apple fruits, Advances in science for agriculture: proceedings of all-Russian scientificpractical conference, pp 215-218 (2017) (In Russ.)

6. N. N. Gorb, R. D. Babina, A. E. Untilova, Yu. N. Vvedensky, Orchard management, 57, 394-399 (2005) (In Russ.)

7. Barbara Strz, O. Rossi, A. Zanella, Laimburg Experimentation Center, Specialized magazine of the Consultancy Center, 41(3), 10-11 (2017)

8. V. A. Gudkovsky, L. V. Kozhina, Yu. B. Naumov, R. B. Guseva, The achievements of science and technology AIC, 9, 105-108 (2016) (In Russ.)

9. T. G. Prichko, T. L. Smelyk, M. G. Germanova, Proceedings SPNZSW, 23, 253-258 (2019) (In Russ.)

10. E. N. Sedov, T. P. Ogoltsova, Program and methods of breeding of fruit, berry and nut crops (Orel) pp 606 (1999) (In Russ.) 